（4）鉄道高架橋の震害と原因の推定（その 1)

（財）鉄道総合技術研究所 棚村 史郎

同上

（株）京浜急行電鉄

西村 昭彦

同上

井上 章彦

丹生 春雄

\title{
1.はじめに
}

昭和62年12月17日に発生した千葉県東方沖地震（M=6.7）により、京浜急行電鉄久里浜線の水深高架橋 において、RCラーメン柱にひびわれならびに一部かぶりの剝䧺が生じたほか、高架橋上の P C電柱が折 摃するなどの被害を受けた。

㮔々の被害状況から、地震動に対する地洫と高架橋の特性が被害の原因に大きく関わっているものと予 想され、調查を行ったところ、因果関係を説明できる盗料を得ることができた。

本槁では、このうち、被害状況の概要と高架橋および電柱の振動特性を把捏するために実施した衝擊振 動試験 ${ }^{1}$ 、常時微動湖定などの調查結果の概要について報告する。

\section{2. 地震の概要}

気家庁の発表によれば、千葉県東方沖の践央位置 は東経 $14029^{\prime}$ 、北緯 $3521^{\prime}$ 、賑源樑さは $58 \mathrm{~km}$ で地震のマグニチュードは 6.7である。各地の震度 を図1に示す。被害を受けた滈架橋は、京浜急行久 里浜線の三浦海岸駅から三崎口駅へ向かった最初の RCラーメン高架橋で、三浦半島南部に位置する。 震央距離は約 $80 \mathrm{~km}$ て高架橋から約 $800 \mathrm{~m}$ 離れた 地点に設置されている東北・上越新幹線の三浦海岸 地震検知点ではNS方向で $300 \mathrm{gal} 、 \mathrm{EW}$ 方向て 3 $30 \mathrm{gal}$ の最大水平加速度が記録された。また、横須 賀市内の運輸省港焪技術研究听構内の泥岩上に設置 された地震計では最大 $70 \mathrm{gal}$ の加速度を記録して いる。

\section{3. 语架橋と被害の概要}

水樑第 1 间架橋のブロック割りを図 2 に示す。著

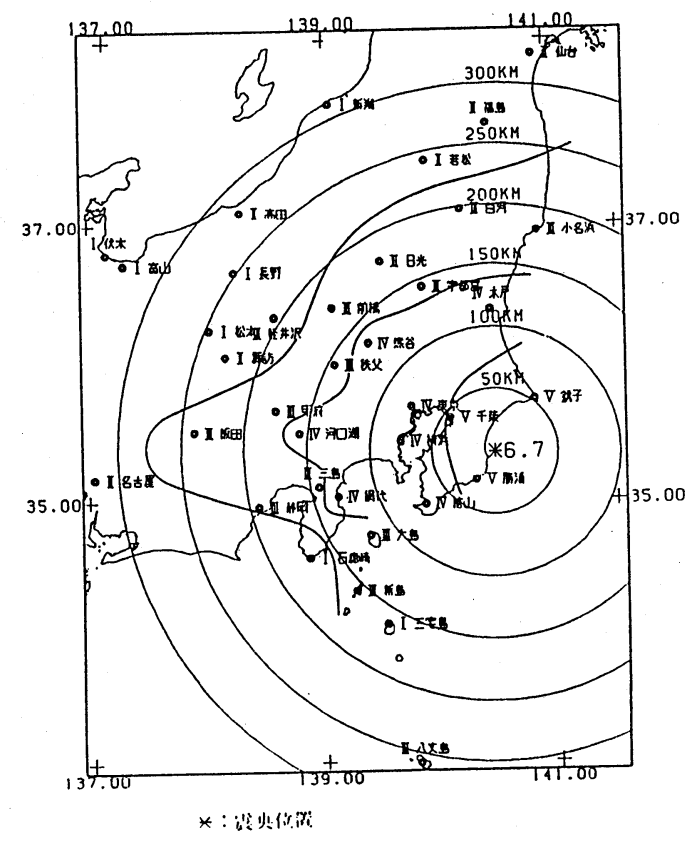

図 1 各地の震度 2

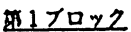

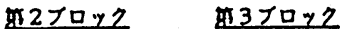

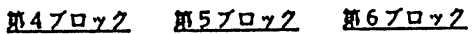
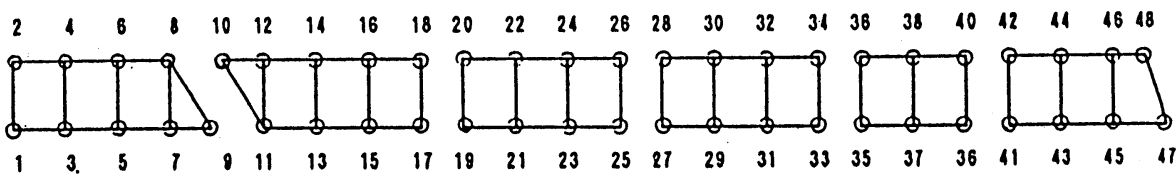

三涑海岸方

三崎口招

図 2 水深第 1 昌架橋ブロック割り 

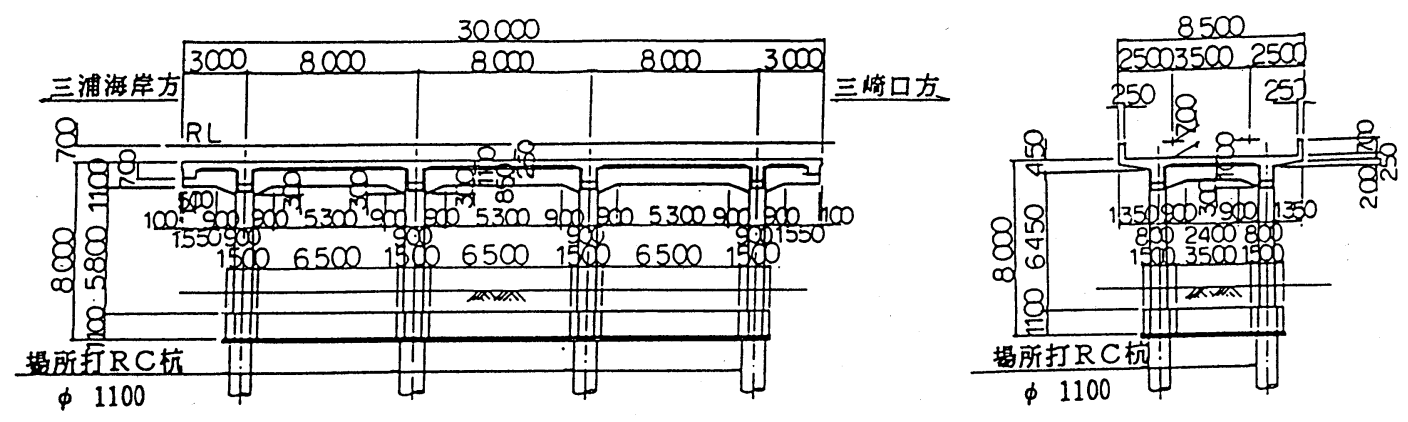

図 3 高架橋一般図

しい被害を受け たのは第 2、第 3 ブロックであ る。第 3 ブロッ クの一般図を図 3 に示す。间架 橋は间さが $8 \mathrm{~m}$ 、 複線支持の 1 居 3 スパン両張り 出し式て、鉄筋 コンクリートの ラーメン構造で ある。基礎は杭 径 $1100 \mathrm{~mm}$ 、長 さ約 $18 \mathrm{~m}$ の場 所打ち鉄筋コン クリート杭から 成る 1 柱 1 杭形

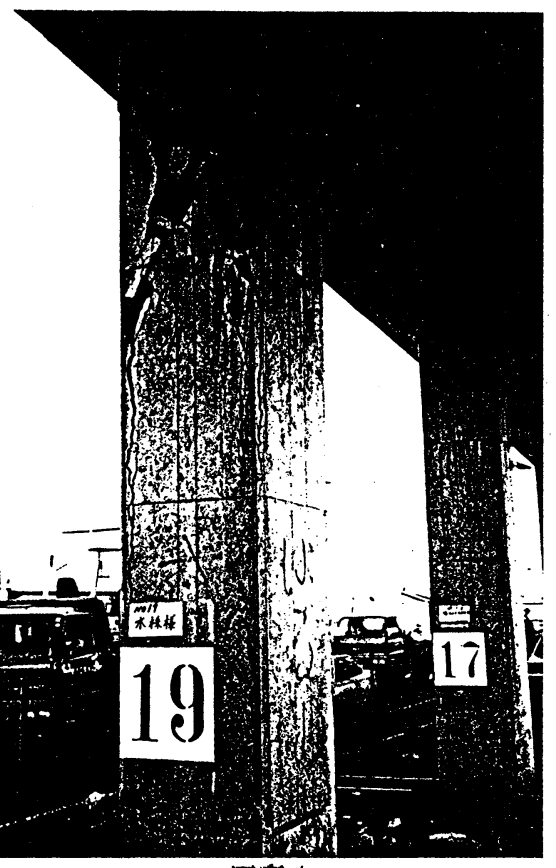

写真 1

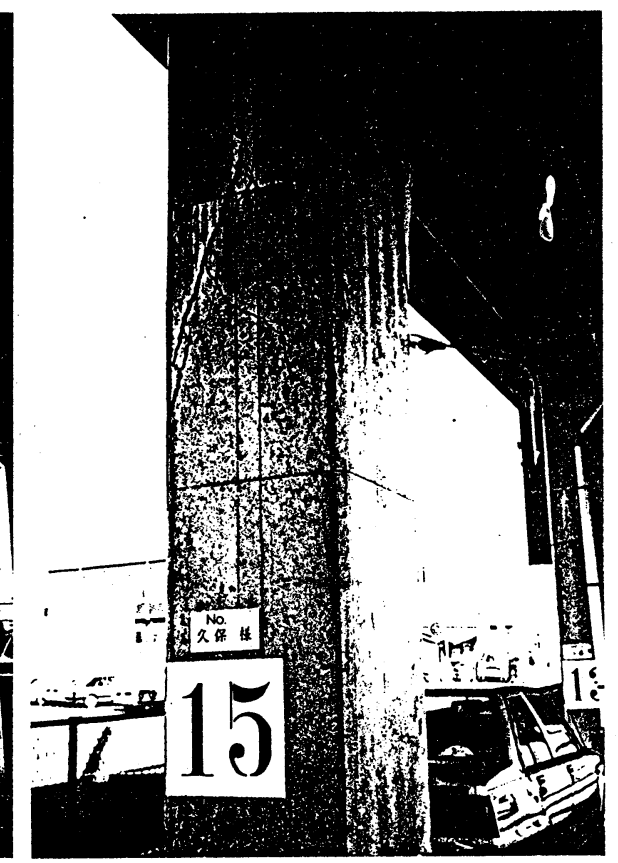

写真 2

式である。主な被害はラーメン滈架橋 の柱上端付近において、ひびわれやか ぶりの刋落（写真 1、2）が生じるな どのせん断破壊を生じたほか、第 $27 ゙$ ロック上の電柱 ( $\mathrm{PC}$ 柱) が支持点よ り約 $0.5 \mathrm{~m}$ 上方の位置で折損（写真 3 ）し、他の 2 本の電柱においても同様 の位置でひび割れを生じた。また、杭 頭部书よび地中梁の状況を調查したと ころ、地中梁の一部にせん断ひびわれ がみられたものの他に異状は諗められ なかった。なお、スラブおよびスラブ 上居梁は被害を受けていない。

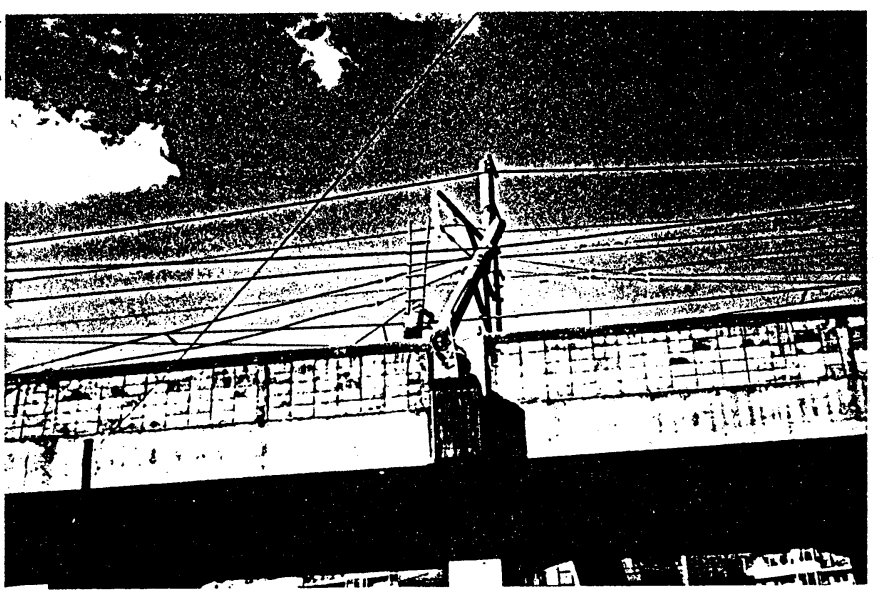

写真 3 


\section{4. 地形、地算の概要}

高架橋の位置する三浦半島南部は、東は東京浮に、南と西は相檔湾に面しており、最終間水期の海退に 伴って、段丘上に細かい樹枝状の谷か形成され、沖糟世の海進と共に漻れ谷が発達した地域である。高架

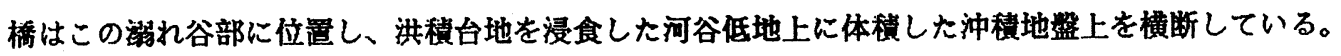

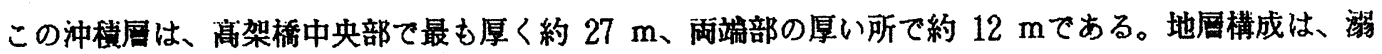
れ谷の底部に堆積した粘性土の上に、抄洲の発達により形成された砂筫土層が分布している。この仯筫土 居は比較的締まっており、N檤は $30 \sim 40$ である。

図 4 に地筫維断図を示すが、高架橋の基礎杭は洪䅡地盤を支持屏として根入れさせている。

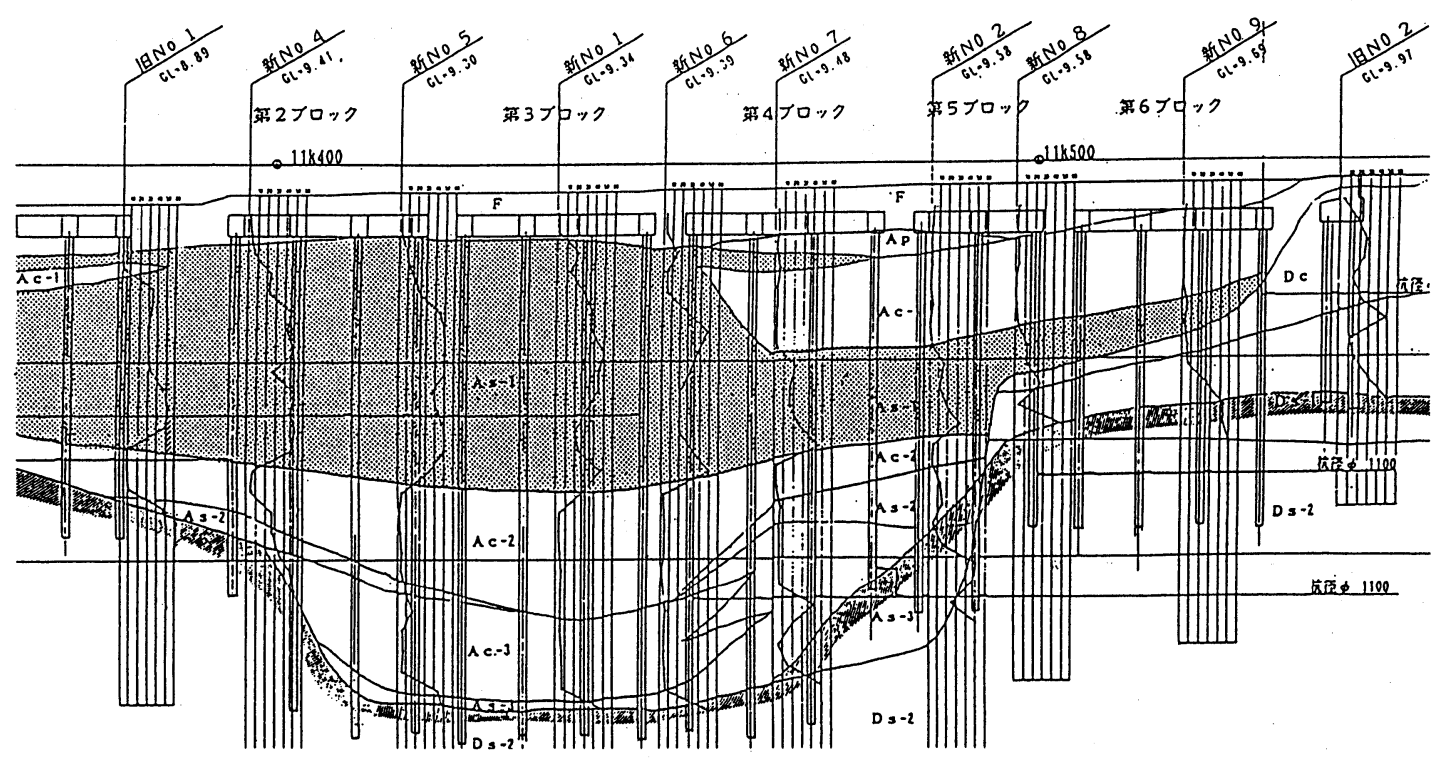

図 4 地算䋛断図

5. 地敶と高架橋および電柱の振動特性

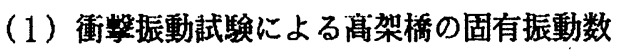

衝慗振動武糇は、重さ $30 \mathrm{~kg}$ 程度の重鏈を用いて、高架橋を打撃し、高架橋の変位または加速度の応答

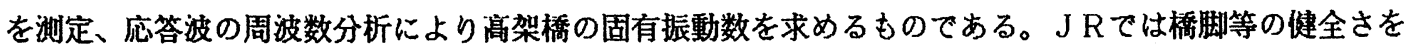
判定するための一つの手法としてこの試矣法が定着している。

衝警振動試糇により求めた 高架橋の固有振動数を表 1 に 併記したが、 $2.55 \sim 2.65$ $\mathrm{Hz}$ の䩪囲にある。図 5 は第 3ブロックのフーリエスペク トルを示したものである。

一方、この高架橋とほほ同 程度の規模を有し、被害を受 けていない近傍の高架橋の测 定では $3.55 \sim 3.95 \mathrm{~Hz}$ の 結果を得ている。

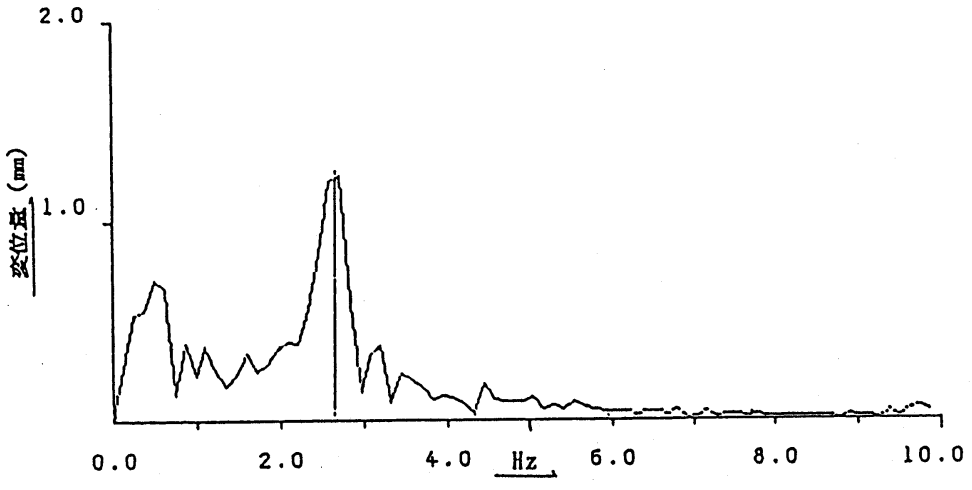

図 5 高架橋の固有振動数（第 3 ブロック） 
（2）常時微動

地盤および高架橋の振動特性

表 1 地盤书よび间架橋の卓越振動数（㛢軸直角方向）

$\left(\mathrm{H}_{z}\right)$

を求める目的で常時微動を湖定

した。表 1 は常時微動测定から

得られた高架橋および周辺地㭰

の橋軸直角方向の卓越振動数を

示したものである。地盤の卓越

振動数は水平成分のフーリエス

ペクトルを上下成分のフーリエ

スペクトルで除した伝達関数を、

泉架橋については高架橋上とそ

の直下の地篮で同時に測定して

得られたフーリエスペクトルの

比で求めた伝達関数を用いて求

\begin{tabular}{|c|c|c|c|c|c|c|c|}
\hline プロ & & 常 & 時 & 微 & 動 & & 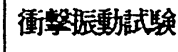 \\
\hline No. & 地 & 盤 & & & 高 & 架 & 喬 \\
\hline 1 & $244: 4.06$ & 4.93 & & 2.59 & $9: 3.22$ & & - \\
\hline 2 & $2.03 \quad 2.59$ & 4.96 & 5.49 & 2.59 & $9: 3.25$ & & - \\
\hline 3 & $1.71 \quad 3.42$ & 3.98 & 4.52 & $2 \%$ & 1: 3.22 & & 2.65 \\
\hline 4 & 1667: & & & $12: 59$ & $9: 3.39 \quad 4.22$ & & 2.55 \\
\hline 5 & $1.66 \quad 2.57$ & 3.47 & & 2.00 & $0: 2: 47: 2.66$ & 3.00 & 2.65 \\
\hline 6 & $1.66 \quad 2.42$ & 4.59 & 5.66 & 2.66 & $6: 3: 00: 3.37$ & 4.25 & $2.65 \quad 3.05$ \\
\hline
\end{tabular}

注）網目を伏した值は顕著な卓越振動数を示す。

めたものである。

地盤ては多くの卓越振動数が得られてお り、直ちに固有振動数を決定するのは難し いか、各湖定点での違いは定性的に土算調 查の結果と一致している。また、高架穚の 伝達関数には数個の卓越振動数が見受けら れるか、フーリエスペクトルの形状等から 勘案して、また、衝数振動試験の結果を勘 案すると固有振動数は $2.5 \sim 2.6 \mathrm{H}_{2}$ の䉇 囲にあるものと推定される。図6に第 3 ブ ロックの卓越振動数の例を示す。

（3）高架橋の固有振動数の推定

常時微動測定および衝㨻振動試験の結果

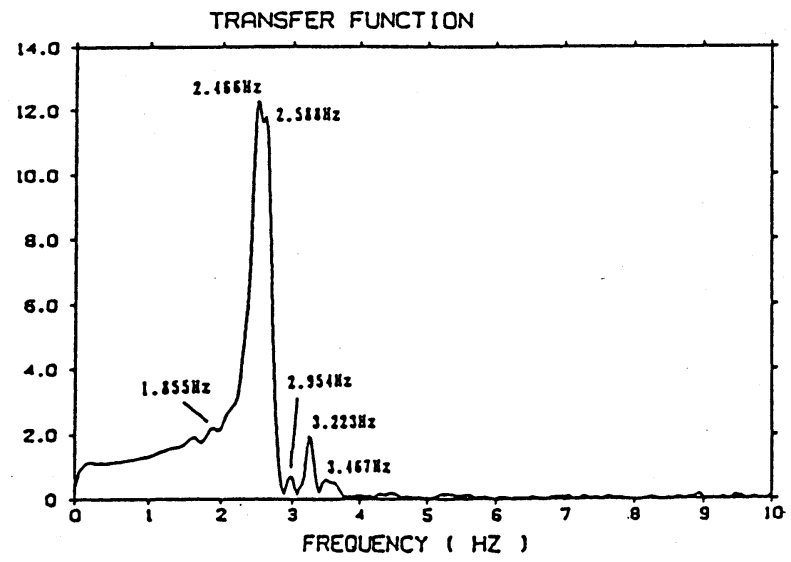

図6 高架橋の伝達関数（第 3ブロック） から、间架橋の固有振動数は 2.5 2.6 $\mathrm{H}_{\mathrm{z}}$ の範囲にあるものと推定された。しかし、同程度の規模を有 し、被害を受けていない他の高架橋の測定例のほか、過去に国鉄において実施された起振機を用いた強制

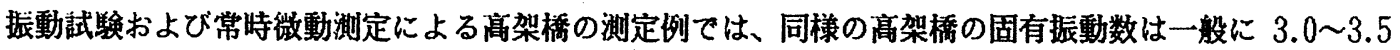
$\mathrm{H}_{\mathbf{z}}$ 程度であり、今回の測定結果は地辰によるひびわれなどで高架橋の用性低下が生じたためと推察され る。

\section{（4）電柱の固有振動数}

電柱の固有振動数は、自由振動寒験および解折により求めた。この結果はき電線重量が作用している山 側とき電線の無い海側とでは異なり、橋軸直角方向でそれぞれ $2.66 \mathrm{~Hz} 、 2.83 \mathrm{~Hz}$ である。なお、折 摃被害を受けた電柱は海側でる。

\section{[参考文献]}

1）西村昭㢁，中野聡；衝靼振動試験による構造物の振動特性の把握，第 19 回地票工学研究発表会, 昭和 62 年 7 月.

2）佐々木康；千葉県東方沖の地震（62.12.17）の調查速報，土木技術資料，Vol.30，No.1，1988. 